\title{
Bespreking en Gesprek
}

\section{A. Boekbespreking:}

GEORGE B SILBERBAUER: BUISHMAN SURVEY REPORT. An Official Report for the Bechuanalund Government, Gaberones, February 1965

George B. Silberbauer het as administratiewe amptenaar van sy tegering opdrag ontvang en deur middel van nagraadse studie aan die Universiteit van die Witwatersrand, vanaf 1958 'n intensiewe studie van die sogenaamde ..wilde" Bnesmans. die $\mathrm{G} / \mathrm{wi}$ stam, in die om. gewing van Ghanzi gemaak. Na ses jaar het 'n omvaltende verslag van ongeveer 124 bladsye en $n$ verdere 6 bladsye aanbevelings, die lig gesien.

Hierdie navorsing is natuurlik van onskatbare waarde vir die sosioloog, ekoloog, antropoloog, volkekundige, aadrykskundige, staatsadministrateur en selfs vir die ibioloog en plantkundige. Die verslag :s egter so insiggewend en lees si) lekker dat dit ook vir die missioloog van groot beiang is.

Silberbauer vind hierdie oudste inwoners van Suidelike Afrika vriendelik, maar sku-skaam teenoor vreendelinge. Hulle is intelligent maar hulle het 'n besonder kor1 konsentrasie-span in hul geesteiike aktiwiteit en absoluut geen belangstelling vir iets wat nie van onmiddellike aktuele belang is nie (p. 9). Dit is vanselfsprekend belangrike feite waarmee in die sendingbenadering rekening gehou moet word. Misverstand van hulle geaardheid kan ligtelik lei to 'n foutiewe oordeel. Die Boesman se belangeloosheid by dit wat vir die navorser of sendeling van groot belang is, kan verkeerdelik as "mental inferiority" vertolk word. Silberbauer sê: .. In six years among the G/wi. I have done tittle more than scratch the surface of ihcil culture and glean an clementary understanding of them. their way of lite and their language. Other social anthropologists are presently active in the field. notably Mr. Richard Lee... Dr. H. J. Heinz ..." (p. II).

Die sendıngwetenskap sal moet kennis neem van die demografiese. ekonomiese. ekologiese, godsdienstige en inter-etniese verhoudings waaroor in hierdie verslag uitvoerig gehandel word. Om die evangelie oncer so 'n tipiese nomadiese jugterswolk te bring. verg in besondere benadering. Dit is amper ' $n$ vraag hee die evangelie wat baie vas is in so 'n onstabiele leefwyse sal pas! In hierdie verband moet verder in gedagte gehou word dat dic Boesman sc stamgewoontes aanmerklik verskil van dié van enige ander volk in Suidelike Afrika. Daar is zeen kaptein-stelsel of stelsel van Boesman-owerhede nie. Boesmans swerf in groepe van ongeveer sestig. Die gemeenskaplike opinie geld as die recl. dissipline en wel in claardie groep. Daar kan dus nic sprake wees van kerstening van ' $n$ hoof met die gedagte dat dit die 
stam in 'n sckere rigting sal stuur nie. In die lente breek die groepe $o p$ in klein familie-eenhede met die oog op die skaarste aan voedsel. Die sendeling sal moet aansluit by die invloed en gesagstruktuur van die ouers, by die „clan” en vera! by die unieke en ten volle geemansipeerde posisie van die Boesman-vrou. Miskien moet juis die vrou (sonder dat dit 'n matriargale stelsel is) as die stabiele faktor in die Boesman samelewing en ekonomie aangcmerk word.

Silberbauer meen dat in Boesman gemiddeld nie ouer as 45 jaar word nie (p. 92). Die sendeling kan gevolglik nie verwag dat die evangelie deur 'n ouer geslag van Boesman-christene gedra en ingedra sal word nie.

Die sendingwetenskap kan wel uit die navorsing van Silberbauer sckere punte vind waarby aangesluit kan word, byvoorbeeld die Boesman se verantwoordelike benadering tot die natuur. Hy jag en oes uit godsdienstige motiewe net mel die oog op sy lewensonderhoud. Hy jag nooit vir sport of vir die genot van doodmaak nie. 'n Sendeling moet dink aan dic besonder sterk bande van kameraadskap (naasteliefde?), waarop die Boesman-samelewing en selfs die jagpartye georganiseer is. Dit is 'n samelewing met 'n natuurlike gemeenskaplike besit en bestaan (vgl. Hand. 2). Hierdie kommuniale leefwyse ontstaan nie tit 'n ideologie scos die Kommunisme nie.

Vir die teoloog is Silberbauer se uitvoerige behandeling van die Boesman se opvattings oor godsdiens, bo-natuurlike wesens en die dood van besondere belang Dit is merkwaardig dat hierdie primitiewe mense. afgesonder in Suidelike Afrika gedurende die afgelope twaalf tot vyftienduisend jaar, 'n monoteistiese geloof bewaar het en die dualisme van goed en $\mathrm{kw}$ sad uit die geestelike wêreld ken. N'odima leef in die hemel en is mensvormig: onsigbaar en onvernietigbaar; alwetend en alomteenwoordig. Hy het cie wêreld oorspronklik goed geskape. Daarteenoor ken die Boesman vir G/awama, wat onverpoosd probeer on $N^{\prime}$ (xdima se werk te bederf. $H y$ is die onrsaak van ongelukke. siektes en verkcerde optrede bv mense. Gevolglik meng N'odima vegs insidenteel in by gebeurtenisse op aarde (p. 95 e.v.). Hoewel $N^{\prime}$ edima antropomorf gesien word. is hy hoegenadmd nie aan menslike heperkinge onderhewig nic. Die Boesman maak hon nie verder moeg oor die woonplek of natuur van $N$ 'rrdima nie. Hy probeer gevolglik nie met N.odima gemeenskap oefen deur gebede, liedere of offers nie. Daar is gevolglik onder die Boesmans geen priester of godsdienstige voorganger nic.

N'odima is die skepper van lewe. Gevolglik mag diere (selfs insckte) slegs met 'n gocie doel voor oë gedood word (p. 95), anders mag $N$ 'ondima steawwend ingryp. Hy shep lewe in swangerskap. maar dic scksuele gemeenskap kom van (j/arsama en is kwadj.

(i/awama is ook in onsigbare en semi-antropomorfe wese. $\mathrm{Hy}$ heinvloed mense ten kwade Die Boesmans glo dat veral die vrovens deur die slegte gees van Ci/an'ama aangetas word. Hy word gevolglik bestry met eksorsie-danse. te wete die (jemsbok. en Ysterdanse. Die mens moel die kwad uit die vroue deur middel van hulle hande trek 
terwyl hulle rondom die sittende vroue dins. Wanneer in man die kwaad absorbeer, raak hy in vervoering en weldra in beswyming. "almost or completely unconscious. The trance after collapse may be cataleptic, with a very slow pulse rate. or even absence of pulsebeat and very low skin temperaturc ... Other men in trances show very high pulse rates ... and sweating ..." (p. 97).

Hoewel $N^{\prime}$ odima nie aangeroep word nic. word dit wel met dic reën, die son en die maan gedoen. Hierdie natuurverskynsels word in in sekere sin ook antrcpomorf gesien (p. 10) e.v.). Omdat die Boesman nie die natuurlike en bo-natuurlike soos ons skei nie. "their attitudes and beliefs concerning $N^{\prime}$ odima and $G / a w a m a$ and the (to us) natural phenomena of sun, moon. and rain are casual, confused and very difficult to obtain and put into any sort of order" (p. 1(2). Daar is in variasie tussen die opvattings en praktyke van verskillende Boesmanstamme.

Die $\mathrm{G} /$ wi glo in die voortbestaan van dic siel na die dood. maar hulle sien geen verband tussen dic lewe en die toestand van die siel na die dood nie. Daar is geen hemel of hel nie. Hoe jonger iemand sterf hoe meer $k$ waadaardig is sy gees vanweë die verbreking van sy band met sy farnilie en groep. (jevolglik is so in gees gevaarlik en vermy die Boesman die graf so gou as moontlik

Silberbauer gee in sy slothoofstukke (p. 114 e.v.) 'n historiese en ekonomiese analise van die gekompliseerde situasie wat ontstaan het roe die Europese hoer as werkgewer teenoor die tupiese Boesman as werknemer te staan gekom het: gekompliseerd vir die Boesman wat uit 'n radikaal ander sosiaal-ekonomiese wêreld kom en hom moet handhaaf in die kapitalisties-europese strukluur. Wat hom juis sy bestaansmoontlikheid in dic: woestyn stelselmatig ontneem. Hierdie aanraking van mense uit die latere steen-tydperk met die mens van die twintigste eeu is inclerfaad in gekompliseerde verskynsel (vgl. p. 123).

Tussen die Boesman en Banlu het gaandeweg ook 'n ciesoortige sisteem van beskermheer en kliént ontwikkel. Dit is opmerklik dat hierdie natuurlike ontwikkeling die patroon van afsonderlike ontwikkeling vertoon. waar die Boesmans in "their own village some distance" van dié van die Bantu-beskermheer gaan woon (p. 128). Die afhanklike ekonomie van daardie Boesman is deels geintegreerd by en word deel geinisieer deur dié van die Bantu skutsheer. 'n Mens kom onwillekeurig onder die indruk dal dié natuurlike ontwikkeling in die Kalahari-woestyn tussen Bantu en Boesman grotendeels 'n replika bied van dit wat tussen Blanke en Bantu in Suid-Atrika ontwikkel het. In hierdie geval noem die Boesnians hulle Bantubeskermheer "owner" en hy beskou hulle "born as his property". Tog is Silberbauer oortuig dat "the system of patronage and clientage does not amount to slavery as has sometimes been alleged. Slavery entails a state not entered voluntarily ... The mere absence of cash reward is, in itself, insignificant in an undeveloped country like Bechuanaland ..." (p. !30). "In general, Bantu regard Bushmen as inferiors, which they certainly are as far as technological achievement is concesned. and 
some even equate Bushmen wilh baboons or monkeys ... Fortunately the view is held by a very small minority. The Tswana are a courteous people and are more inclined to kindness towards others .." (p. 131). "The Bushmen are conscious of their separate idenlity. but have neither pride nor shame in it and would have little resistance against being absorbed into the Bantu pupulation". Die proses sal egter baie langsaam voltrek word, op grond van die Bantu se meerderwaardige selfwaardering ten opsigte van die Boesman (p. 131). Die feit is seker korrek waargeneem. maar die interpretasie te eng. Silberbauer is van mening dat hoofsaaklik ekonomiese faktore hierdie "prejudice" skep (p. 135)!!

Hoewel dit vir die doel van hierdie kommentaar op Silberbauer se verslag onnodig is. merk 'n mens $\log$ op dat Silberbauer klaarblyklik ook besondere fisieke raseienskappe by die Boesmans vasgestel het, byvoorbeeld. lewensduur, vrughaarheidsperiode. natuurlike kinder-spasiëring, totale afwesigheid van tweelinge. ens., afgesien van die meer bekende cienskappe soos grootte. agterstewe, kopbeen. ens.

So $n$ indringende analise in die mense van ons buurstaat Botswana. al is dit gedoen deur iemand met $n$ ander lewensbeskouing. bied vir ons baie stof en feite wat ook missiologies vertolk moet word, indien die kerstening van die Boesmans, soos deur die Ciereformeerde Kerke in S.W.A. ter hand geneem. op wetenskaplike bane moet geskied. 'n Eksemplaar van die verslag is in die Biblioteek van die Teologiese skool op Hammanskraal heskikbaar.

B. SPOEL STRA. 